\title{
Analysis of the Current Situation of Financial Poverty Alleviation Funds in Henan Province Under the Background of Rural Revitalization Strategy
}

\author{
Xiaoyu Liu ${ }^{1,2, a, *}$, Xiaofu Liu ${ }^{3,4, b}$ and Zhenpeng Guo ${ }^{5, c}$
}

\author{
${ }^{1}$ Wuhan University of Technology, Wuhan, Hubei, China \\ ${ }^{2}$ Zhengzhou Normal University, Zhengzhou, Henan, China \\ ${ }^{3}$ Zhengzhou Airport Economic Comprehensive Experimental Zone, Zhengzhou, Henan, China \\ ${ }^{4}$ Wuhan University of Science and Technology, Wuhan, Hubei, China \\ ${ }^{5}$ Zhengzhou bank, Zhengzhou, Henan, China \\ ${ }^{a}$ zzsylxy@126.com, ${ }^{b} 9400635 @ q q . c o m,{ }^{c}$ guozhpg@126.com \\ *Corresponding author
}

\begin{abstract}
Financial poverty alleviation funds is an important material basis for ensuring social stability and promoting the development of the cause of poverty relief. It is not only an economic issue but also a political issue to properly manage and use the special financial poverty alleviation funds. During the two sessions, "targeted poverty alleviation and elimination" has become a hot topic among deputies and members, and the use of poverty alleviation funds has drawn great attention from all sectors of society. In recent years, the scale of poverty alleviation funds has increased dramatically. How to ensure that these funds are put in place, used safely and achieved results has become a major issue that attracts wide attention of the society and is eagerly awaited by the masses. On the basis of elaborating the new trend of financial poverty alleviation funds in Henan province in recent years, this paper deeply analyzes the existing problems in the use and management of financial poverty alleviation funds so as to recognize the current situation of financial poverty alleviation funds and use the funds better.
\end{abstract}

Keywords: poverty alleviation funds, targeted poverty alleviation and elimination

\section{INTRODUCTION}

In recent years, the scale of poverty alleviation funds has increased dramatically. How to ensure that these funds are put in place, used safely and achieved results has become a major issue that attracts wide attention of the society and is eagerly awaited by the masses. Since the implementation of the strategy of precise poverty alleviation and precise poverty relief, "four tangible measures", "five one batch", "six precise measures" and other measures have been carried out in depth. As an important poverty alleviation resource led by the government, the use and management of financial poverty alleviation funds have undergone great changes: the scale of poverty alleviation funds has increased substantially; the power to approve projects has been fully delegated; the overall integration of agricultural funds has been intensified; the dynamic monitoring of poverty alleviation funds has been fully covered; and a high-pressure situation of fund supervision has taken shape. However, there are still a lot of problems in the special inspection of poverty alleviation funds, such as unused funds, surplus seriously, improper use of funds and methods of disbursement, overdue application for account or incomplete accounting information, inadequate implementation of funds management system, slow progress in the implementation of projects, non standard examination and project changes, and management of poverty alleviation projects, the implementation of the system is not in place, and the unsoundness of the system of integrating funds related agriculture.

\section{NEW TRENDS IN FINANCIAL POVERTY ALLEVIATION FUNDS}

\subsection{The Scale of Poverty Alleviation Funds has Increased Substantially}

The financial poverty alleviation fund is the foundation and guarantee of the livelihood project of poverty relief. In recent years, China's finance at all levels has been actively adjusting and optimizing the structure of fiscal expenditure, taking poverty relief as a priority, and the total amount of financial poverty alleviation funds has increased substantially and continuously. [1]According to statistics, the central government has invested 280 billion yuan in special poverty alleviation funds over the past five years, especially more than 140 billion yuan from the central and local governments in 2017. In 2017, 53 poverty-stricken counties in Henan province received more than 30 billion yuan of agricultural funds. In 2018, Henan has allocated 4.04 billion yuan of special poverty alleviation funds from municipal and county finance, including 3.13 billion yuan from the central government and 910 million yuan from the provincial government. The total amount of financial poverty alleviation funds has increased significantly. Precise poverty alleviation requires that the financial poverty alleviation fund must be arrive in every village and every household. There are many problems in the management of financial 
poverty alleviation funds, such as large scope, long distance, and much aims.

\subsection{The Power to Approve Fund Projects has been fully Delegated}

In recent years, the central government has cancelled more than 10 tasks of special projects and pilot projects. Since 2014 , the power to approve special poverty alleviation funds has been placed at the county level, and the proportion of such power has been increased year by year, from $75 \%$ in 2014 to $95 \%$ in 2016 . In 2015 , according to the financial resources per capita, the disposable income per capita, the number of poor people, the actual needs of poverty relief in the current year, Henan has cut the special poverty alleviation funds into the cities and counties. According to the actual needs of the cities and counties, the special poverty alleviation funds are used in industry of poverty alleviation, infrastructure of medical assistance of poverty alleviation, the transfer of the poor to training for new jobs, and rural practical technology training. The process of approve poverty alleviation fund projects has been changed from "county-level declaration, municipal-level review, provincial-level approval" to "county-level approval, provincial-record". [2]The power to approve poverty alleviation fund projects has been fully delegated to the county. The new approval process simplifies application procedures, strengthens the responsibility of the county, optimizes the efficiency of the use of funds, weakens the stylized rituals of business departments at all levels, and improves the pertinence, effectiveness and practicality of projects.

\subsection{The Dynamic Monitoring of Financial Poverty Alleviation Funds has been Fully Covered}

At the end of June 2017, the dynamic monitoring system of financial poverty alleviation funds in Henan was formally put into operation across the province. The system is based on the provincial exclusive cloud platform for government affairs, and successfully applies cloud computing, big data and other technologies. Up to now, the provincial financial poverty alleviation funds have been included in the monitoring scope, basically realizing the dynamic tracking of the whole process of poverty alleviation funds operation. The dynamic monitoring system of financial poverty alleviation funds in Henan adopts three tracking and monitoring modes, which are divided into areas, departments and financial internal business organizations. The system shows the provincial financial poverty alleviation funds in real time, shows the composition of special poverty alleviation funds and integral funds in the level of province, city and county according to the hierarchical level, automatically collects and updates the change of how to use funds in the provincially administered municipalities and counties, and shows the distribution and payment of funds in real time. In addition, the dynamic monitoring system of financial poverty alleviation funds in Henan can obtain when and where each poverty alleviation fund is distributed in real time, and can show some specific information such as paying units, paying accounts, paying time, paying purpose, the beneficiary and the collecting account. The poverty alleviation has realized chain tracking from the budget arrangement to the final payment. [3]

\subsection{High-pressure Situation of Fund Supervision has Taken Shape}

In recent years, the departments of finance, poverty alleviation, audit and other departments have continuously strengthened the supervision of the poverty alleviation funds, and have launched and implemented the supervision and enforcement accountability for poverty alleviation, the regulation and prevention for duty crime in poverty alleviation fields, the centralized check and performance evaluation for special financial poverty alleviation funds, the use and management for poverty alleviation funds and the tracking audit for the related policy, warning education for the poverty alleviation system, the establishment of hotline for public report and supervision for poverty alleviation, and the fully implementation of the public announcement system. These measures enable to keep high pressure situation of the poverty alleviation funds supervision, and the condition of the use and management of financial poverty alleviation funds has been generally improved. Over the past two years since the launch of the hotline 12317, which is the hotline for public report and supervision, the State Council Leading Group Office of Poverty Alleviation and Development of China has received more than 10,000 phone calls. The illegal and discipline-violating problems relating to poverty alleviation funds have attracted wide attention in the whole society.

\section{PROBLEMS IN FINANCIAL POVERTY ALLEVIATION FUNDS}

\subsection{Poverty Alleviation Funds Unused and Surplus}

Some projects cannot be implemented due to changes in subjective and objective conditions, but the financial department fails to recover the funds in time, resulting in the fact that the funds cannot form actual expenditures within the specified time, and some even idle for more than 2 years. Some poverty alleviation funds are allocated to the competent departments or villages and towns, but not to receive specific projects, also resulting the funds remained idle for a long time.In addition, due to the number of changes caused by accurate identification, some of the funds of the subsidy projects issued directly to the individual of the poor failed to pay successfully. The special financial account in long-term detention or bank account in transition also aren't timely taken back to the Treasury and arranged for the poverty alleviation project, directly affecting the use efficiency of poverty alleviation funds.

\subsection{Improper Use of Funds and Methods of Disbursement}


Some of the household projects use special financial poverty alleviation funds to support the poor households. After checking the list of poor people's files and cards, they find that some of the supported aren't poor, and even there are cases of obtaining illegally financial poverty alleviation funds. In addition, there exists the case of expanding the scope of expenditure in the process of implementation of the project, using financial funds for daily spending, such as overdue subsidies, hospitality, wine for entertainment, and printing of engineering drawings. What's more, the distribution method of the training poverty alleviation projects funds relating to direct subsidies for poor households is not compliant. [4]The ministry of finance allocates funds to the training organizations, without authorizing financial institutions to directly distribute funds to poor households in the form of one-card or union pay card.

\subsection{Overdue Application for Account or Incomplete Accounting Information}

The industrial poverty alleviation projects in some poor counties have been completed or settled, but due to the overdue application for account or incomplete accounting information of the project funds, some funds can't in the place. As for some poverty alleviation projects of infrastructure, although the financial departments have urged the competent departments and project construction units to apply for the accounts in time in accordance with the requirements of the periodic reimbursement, part of the project construction units tend to adopt the method of one-time reimbursement after complete inspection and acceptance, in order to reduce the number of reimbursement. And the account information is not compliant and not complete, the funds can't be in place in time, resulting the condition that the project progress don't match funds spending, which directly affects the progress of the expenditure of funds. [5]

\subsection{Inadequate Implementation of Financial Poverty Alleviation Funds Management System}

Financial departments of some poor counties do not apply county-level reimbursement and ledger accounting as required, but directly allocate annual project management fees to poverty alleviation departments, or directly allocate additional project funds to rural accounting stations. For example, the finance bureau of a county incorporates the central lottery public welfare fund in 2015 to support the small public welfare facilities construction projects of the revolutionary old areas into the special accounts of the financial poverty alleviation funds, and check together with industry development project funds such as the whole village promotion and the industrial discount interest, rather than carry out county-level reporting and check out based on different accounts as requested. In addition, besides the special funds issued by the central and provincial departments, some projects are supposed to received funds from municipal and county-level departments. However, funds of municipal and county-level integration departments often aren't in place or delay without reason. [6]

\subsection{Non Standard Examination and Project Changes}

The projects of breeding and planting type such as household income and poverty alleviation through science and technology, need to rely on relevant professional cooperatives and enterprises to implement. But when the poverty alleviation project departments select the professional cooperatives, they don't study enough for the related business qualification and the ability of management, even conclude a contract for the purchase and sale before registering and set up a cooperative. In addition, due to the change of objective conditions, some poverty-stricken counties arbitrarily changed the implementation content of industrial poverty alleviation projects or the length and width of roads and other engineering quantities in infrastructure construction, but not fulfilling the corresponding change procedures, and not reporting to the provincial records as required. [7]

\subsection{Bad Implementation of the Poverty Alleviation Management System}

First, government procurement is not carried out as required. When some poverty-stricken counties use poverty alleviation funds to purchase materials and other items in the industry poverty alleviation programs, they don't perform government procurement as required. Second, the financial investment review and completion financial final accounts are not conducted as required. Some poverty-stricken counties use special financial funds to promote road construction projects in the whole village. After completion, the funds have been paid before the assessment by the financial investment evaluation center. [4]And they hand over the completed project after the completion of road construction tasks, but the financial accounts for the completed project have not been compiled as required. Third, the project information is not disclosed as required. For example, the poverty relief office of a county added the program of chicken farming in 2016, and used special financial poverty alleviation funds to support the poor households, but the list of demonstration households, project content, fund amount and other project information were not published in the open column of village.

\subsection{Unsoundness of the System of Integrating Funds Related Agriculture}

Firstly, the usage scenarios and management methods of integrating funds are not detailed and clear. For example, in November 2016, although the government of a county formulated and issued The Implementation Plan for Integrating and Using Financial Agricultural Funds, the operational process of integrating funds was not detailed, nor did it specify the subsidy standard, performance target, time schedule and implementation place for integrating and using financial agricultural funds. In addition, the county's ministry of finance shall put central and provincial financial funds related to agriculture into the area of poverty alleviation, which is arranged by financial budget, but not incorporate usage scenarios of integrating financial funds 
related to agriculture, which are reported to the provincial level for filing. Secondly, the overall integration of funds accounting treatment is not standard. For example, a poverty-stricken county did not establish a general and integrated fund management ledger, did not distinguish various funds of the central government and provincial levels and recorded the sources of budget indicators in detail, did not list corresponding expenditure items according to actual use, and recorded the related fund use adjustment in the budget index account. [8]

\section{CONCLUSIONS}

Financial poverty alleviation funds are an important material basis for ensuring social stability and promoting poverty alleviation. It concerns not only the vital interests of the people, but also the image of the party and the government. Therefore, it is necessary to analyze the current situation of financial poverty alleviation funds.

\section{ACKNOWLEDGMENT}

This research was financially supported by The 2019 Annual Research Project of Henan Province Federation of Social Science and Technology (SKL-2019-3357) and The 2020 Research Project of Henan Science and Technology Think Tank (HNKJZK-2020-37C).

\section{REFERENCES}

[1] $\mathrm{Hu}$ jinglin. Increasing financial support for poverty alleviation. Administrative reform,2016(8).

[2] Yuan gang. Analysis on the management of financial poverty alleviation funds. Western finance and accounting,2017(2).

[3] $\mathrm{Li}$ hancai. Problems and countermeasures of rural financial poverty alleviation fund management. People's BBS,2015(20).

[4] Li yanzhi. Making poverty alleviation funds operate in the sunshine -- the special inspection of financial poverty alleviation funds was launched. Finance of China,2017(7).

[5] Li guiying. Research on targeted poverty alleviation strategies driven by accounting and auditing. Silk road vision,2016(18).

[6] Zheng xu. Special poverty alleviation funds should be "fully invested, fully funded and fully in place". Times report,2017(17).

[7] Zhang bei. Thoughts on strengthening the management of special financial poverty alleviation funds. China finance, 2014(14).

[8] Ministry of finance, poverty relief office of the state council. Notice on further integrating agriculture-related funds in poverty-stricken counties. Contemporary rural finance and economics, 2016(12). 